\title{
Les dialogues à Fukushima
}

Dans ce numéro 2 de l'année de Radioprotection, nous publions une synthèse des dialogues à Fukushima, initiés par la CIPR à la suite de l'accident de la centrale nucléaire du 11 mars 2011. Cet article est présenté par Jacques Lochard et ses collègues. Cette synthèse montre bien l'évolution de la conception de la radioprotection en situation post-accidentelle depuis l'accident de Tchernobyl. Cette évolution trouve ses racines dans le travail réalisé sur le terrain dans les districts les plus contaminés de Biélorussie au cours des projets européens ETHOS et CORE, qui a montré l'importance du dialogue et de l'accompagnement pour permettre une meilleure compréhension de la situation radiologique par les populations impactées et donc une qualité de vie améliorée. Ceci s'est concrétisé dans les publications 109 et 111 de la CIPR. Il en ressort que la radioprotection en situation postaccidentelle doit s'appuyer sur l'écoute des populations impactées et sur le soutien aux initiatives locales pour le développement d'une culture de la radioprotection pour la reconquête des territoires dans des conditions acceptables par tous. Ces concepts impactent également de façon significative la posture et le rôle de l'expert en radioprotection dans ces situations. Ces principes d'éthique en radioprotection sont repris dans la publication 138 de la CIPR et font encore l'objet de nombreuses discussions, et en particulier dans le groupe de travail 109, pour l'éthique en radioprotection médicale. Cependant, gageons que le principe d'implication et de dialogue avec les parties prenantes deviendra dans les années futures un principe incontournable dans toutes les actions de radioprotection et pas seulement en situation post-accidentelle.

Vous trouverez également dans ce numéro un article de A. Yeung qui fait une analyse bien particulière du principe ALARA via les occurrences bibliométriques du mot dans la littérature et un commentaire éditorial associé de J. Repussard, notamment au sujet du futur de la mise en œuvre de ce principe.

Et faut-il le rappeler nous aurons l'occasion d'assister à de nombreuses présentations lors du congrès national de radioprotection à La Rochelle du 17 au 20 juin. Alors pensez à notre revue et transformez vos présentations qu'elles soient orales ou affichées en articles. En résumé, à vos plumes!

\section{The Fukushima dialogue meetings}

In this second issue of Radioprotection, a synthesis of the Fukushima dialogue meetings, initiated by ICRP following the accident in the nuclear power plant on March $11^{\text {th }}, 2011$, is published by J. Lochard and colleagues. This important article clearly shows the evolution of the concepts of radiological protection in post-accidental situations since the Chernobyl accident. This evolution roots in the work conducted in the frame of the European projects ETHOS and CORE in the most contaminated districts of Belarus which demonstrated the importance of dialogue and accompanying strategy in order to gain a better understanding of the radiological situation by the impacted populations and thus a better quality of life. This was depicted in the ICRP publications 109 and 111. As a consequence, the radiological protection in post accidental situation should emphasize listening of impacted populations and should support local initiatives for the development of a radiation protection culture for the recovery of contaminated areas in acceptable conditions for everyone. This conceptual approach of radiation protection also questions the positioning and the role of the experts. The corresponding ethical principles in radiation protection are presented in the ICRP 138 publication but are still the matter of discussion, especially in the task group 109 about ethics in medical radiation protection. However, let's imagine that the principle of implication and dialog with stakeholders will become in the future an unavoidable principle in all radiation protection actions, and not only in post accidental situations

You will also find in this issue an article of A. Yeung with a peculiar analysis of ALARA via the bibliometric occurrences of the word in the literature and an editorial comment of J. Repussard, notably regarding the future of implementation of this principle.

And last but not least, we will assist to numerous presentations in radiation protection during the next SFRP national meeting in La Rochelle, from $17^{\text {th }}$ to $20^{\text {th }}$ of June 2019 . So think about our journal and please turn your quality presentations, either oral or poster, into manuscripts that we will receive with pleasure at the Journal office. So, grab a pen! 